\title{
Leptin Promotes Meiotic Progression and Developmental Capacity of Bovine Oocytes Via Cumulus Cell-Independent and -Dependent Mechanisms ${ }^{1}$
}

\author{
Fabíola F. Paula-Lopes, ${ }^{3,4,5,7}$ Marc Boelhauve, ${ }^{3,5}$ Felix A. Habermann, ${ }^{6}$ Fred Sinowatz, ${ }^{6}$ \\ and Eckhard Wolf ${ }^{2,5}$
}

\begin{abstract}
Institute of Molecular Animal Breeding and Biotechnology, and Institute of Veterinary Anatomy, Histology, and Embryology, ${ }^{6}$ Ludwig-Maximilians University, 81377 Munich, Germany

Laboratório de Biotécnicas da Reprodução ${ }^{7}$, Departamento de Medicina Veterinária da Universidade Federal Rural de

Pernambuco, 52171-900 Recife-PE, Brazil
\end{abstract}

\section{ABSTRACT}

Leptin has been shown to exert positive effects during the maturation of bovine oocytes, influencing blastocyst development, apoptosis, and the transcript levels of developmentally important genes. The present study was conducted to characterize further the mechanisms of leptin action on oocytes and the role of cumulus cells (CCs) in this context. In the first series of experiments, cumulus-oocyte complexes (COCs) were matured in serum-free medium that contained 0,1 or $10 \mathrm{ng} / \mathrm{ml}$ leptin or in medium that was supplemented with $10 \%(\mathrm{v} / \mathrm{v})$ estrus cow serum (ECS). Leptin concentrations of 1 and $10 \mathrm{ng} / \mathrm{ml}$ stimulated the meiotic progression of oocytes. Moreover, TUNEL staining demonstrated that these leptin doses reduced the proportion of apoptotic CCs. In the second series of experiments, COCs or denuded oocytes (DOs) were matured in the presence of 0 or $10 \mathrm{ng} / \mathrm{ml}$ leptin. The percentages of COCs and DOs with extruded polar bodies were increased by leptin. In contrast, positive effects of leptin on fertilization rates and blastocyst development were only observed after treatment of COCs but not of DOs. Leptin treatment of COCs consistently enhanced blastocyst development even after parthenogenetic activation of oocytes or after the removal of CCs before fertilization. The proportion of polyspermic oocytes was not affected by leptin treatment or oocyte denudation. In the third series of experiments, COCs were matured in the presence of 0 , 1 or $10 \mathrm{ng} / \mathrm{ml}$ leptin. The transcript levels of specific genes were determined by reverse transcriptase-quantitative PCR (RT-qPCR) analysis of cumulus cells and single oocytes. Leptin treatment increased the levels of FAS, FASLG, and STAT3 transcripts in oocytes, but did not affect the LEPR, BAX, and BIRC4 mRNA concentrations. In cumulus cells, leptin treatment increased the mRNA levels for LEPR, STAT3, BAX, BIRC4, and FAS, but did not alter FASLG mRNA abundance. In conclusion, leptin differentially regulates gene expression in oocytes and cumulus cells. Moreover, leptin enhances both oocyte maturation and devel-

\footnotetext{
${ }^{1}$ Supported by the Deutsche Forschungsgemeinschaft (Research Unit, Mechanisms of Embryo-Maternal Communication, FOR 478/1).

${ }^{2}$ Correspondence: Eckhard Wolf, Department of Molecular Animal Breeding and Biotechnology, Gene Center, Ludwig-Maximilians University, Feodor-Lynen-Strasse 25, 81377 Munich, Germany.

FAX: +49 892180 76849; e-mail: ewolf@Imb.uni-muenchen.de

${ }^{3}$ These authors contributed equally to this manuscript.

${ }^{4}$ Current address: Laboratório de Biotécnicas da Reprodução, Departamento de Medicina Veterinária da Universidade Federal Rural de Pernambuco, 52171-900 Recife-PE, Brazil
}

Received: 13 June 2006.

First decision: 29 June 2006.

Accepted: 2 November 2006.

(C) 2007 by the Society for the Study of Reproduction, Inc.

ISSN: 0006-3363. http://www.biolreprod.org opmental capacity via cumulus cell-independent and -dependent mechanisms.

apoptosis, cumulus cells, gene regulation, leptin receptor

\section{INTRODUCTION}

Leptin (LEP), which is the 16-kDa product of the leptin gene $L E P$, is a pleiotropic peptide that has been implicated in the reproductive functions of several species [1-4]. There is accumulating evidence that leptin plays a role in the cascade of events associated with oocyte maturation. Previous experiments have demonstrated that leptin supplementation during in vitro maturation (IVM) of bovine oocytes exerts long-term positive effects, as shown by the increased proportion of oocytes that develop to blastocysts, increased blastocyst cell numbers, and the reduced proportion of apoptotic cells in the blastocysts [5]. Leptin also enhances meiotic progression of pig oocytes and subsequent development of parthenogenetic embryos [6]. In contrast, the evidence for a beneficial effect of leptin during mouse oocyte maturation is controversial. While leptin treatment of mouse cumulus-enclosed oocytes or denuded oocytes (DOs) does not enhance meiotic progression [4], the addition of leptin during culture of mouse follicles increases germinal vesicle breakdown (GVBD) [3].

Leptin and its long receptor isoform (LEPR) have been localized in the female reproductive tract of several species. Leptin has been identified in human [7] and mouse [3, 8] oocytes, in human follicular fluid [7,9], and in granulosa and cumulus cells [7]. Leptin mRNA expression has been described in human granulosa and cumulus cells [7], and in pig oocytes at different stages of follicular development and oocyte maturation [6]. The leptin receptor (Lepr/LEPR) mRNA has been detected in mouse oocytes [10, 11], human granulosa [7, 12] and cumulus cells [7], and in bovine blastocysts [5]. The long transmembrane receptor isoform is believed to mediate most of the leptin signaling through the signal transducer and activator of transcription 3 (STAT3) and mitogen-activated protein kinase (MAPK) pathways [13]. Exposure of oocytes to physiological leptin concentrations increases STAT3 [10] and MAPK [6] phosphorylation.

The bovine oocyte is surrounded by layers of cumulus cells that communicate with each other and with the oocyte through gap junctions. Intercellular communication between the oocyte and cumulus cells plays an important role during oocyte maturation by mediating the cytoplasmic changes required for subsequent embryonic development [14]. Removal of cumulus cells before IVM is detrimental to oocyte maturation in cattle $[15,16]$. There is evidence that IVM of bovine cumulus-oocyte complexes (COCs) induces cumulus cell apoptosis [17] 
mediated by the FAS signaling pathway [18]. The mRNA levels for the cell surface receptor (TNF receptor superfamily, member 6, FAS) and its ligand FASLG have been shown to be higher in atretic follicles than in healthy dominant follicles [19]. Moreover, leptin supplementation reduced the incidence of follicular apoptosis, which suggests that leptin can rescue oocytes and follicles from atresia by suppression of apoptosis.

The present study was performed to analyze the differential effects of leptin on oocytes and cumulus cells. In particular, we evaluated whether: 1) the addition of leptin (1 or $10 \mathrm{ng} / \mathrm{ml}$ ) during the maturation of bovine oocytes affects meiotic progression and the incidence of apoptosis in COCs; 2) the beneficial effect of leptin on oocyte function is mediated by cumulus cells; and 3) leptin differently affects mRNA abundance of genes relevant for leptin signal transduction or apoptosis-related genes in oocytes and cumulus cells.

\section{MATERIALS AND METHODS}

\section{Materials}

Recombinant human leptin (purity $\geq 97 \%$ as determined by SDS-PAGE; endotoxin contamination $\leq 0.1 \mathrm{ng} / \mu \mathrm{g}$ leptin) was purchased from Sigma Chemical Company (St. Louis, MO). Bovine pituitary-derived FSH and LH were purchased from Sioux Biochemicals Inc. (Sioux Center, IA). Frozen semen from various bulls was donated by Rinderunion Baden-Württemberg e.V. (Stuttgart, Germany). Tissue Culture Medium (TCM)-199 with Earle salts was from Biochrom AG (Berlin, Germany). Unless otherwise stated, all reagents used for in vitro production of bovine embryos were purchased from Sigma.

The In Situ Cell Death Detection Kit (fluorescein) was obtained from Roche Diagnostics (Indianapolis, IN). Propidium iodide, 4',6-diamidino-2phenylindole dihydrochloride (DAPI) and polyvinylpyrrolidone (PVP) were purchased from Sigma. The Prolong Antifade Kit was obtained from Molecular Probes (Eugene, OR), RQ1 RNase-free DNase was from Promega (Madison, WI), and RNase A was from Qiagen (Hilden, Germany).

Random hexamer primers, TriZol reagent, DNase, RNaseOut, and reverse transcriptase enzyme Superscript II were purchased from Invitrogen (Carlsbad, CA). HotStarTaq polymerase, RNAlater, and the QIAprep Spin Mini Kit were obtained from Qiagen. The Primer Express 2 software, SybrGreen, and uracil $\mathrm{N}$-glycosylase were from Applied Biosystems (Foster City, CA). EcoRI, dNTPs, and XhoI were purchased from Fermentas Life Sciences (Hanover, $\mathrm{MD}$ ), and glycogen was obtained from Peqlab (Erlangen, Germany).

\section{In Vitro Production of Bovine Embryos}

In vitro-fertilized embryos were produced as previously described [5]. Briefly, ovaries were obtained from slaughtered cows, washed several times with PBS, and COCs were obtained by aspiration. The COCs were washed twice in serum-free oocyte maturation medium (TCM-199 with Earle salts that contained $22 \mu \mathrm{g} / \mathrm{ml} \mathrm{FSH}$ and $8 \mu \mathrm{g} / \mathrm{ml} \mathrm{LH}$ ) that was supplemented with $1 \mathrm{mg} / \mathrm{ml}$ polyvinyl alcohol. Groups of $30 \mathrm{COCs}$ were placed in 4-well plates that contained $400 \mu \mathrm{l}$ per well serum-free oocyte maturation medium supplemented with leptin $(0,1$ or $10 \mathrm{ng} / \mathrm{ml})$ or $10 \%(\mathrm{v} / \mathrm{v})$ estrus cow serum (ECS) as a positive control. Oocytes were allowed to mature for $20-22 \mathrm{~h}$ at $39^{\circ} \mathrm{C}$ in an atmosphere of $5 \%(\mathrm{v} / \mathrm{v}) \mathrm{CO}_{2}$ in humidified air. After IVM, COCs were washed in IVFTALP (modified Tyrode stock solution supplemented with $6 \mathrm{mg} / \mathrm{ml}$ BSA, $0.022 \mathrm{mg} / \mathrm{ml}$ pyruvic acid, and $0.01 \mathrm{mg} / \mathrm{ml}$ heparin) and transferred to 4 -well plates that contained $400 \mu \mathrm{l}$ of IVF-TALP per well. Spermatozoa were purified by the swim-up procedure in Sperm-TALP (modified Tyrode stock solution supplemented with $6 \mathrm{mg} / \mathrm{ml} \mathrm{BSA}$ and $0.11 \mathrm{mg} / \mathrm{ml}$ pyruvic acid) at $39^{\circ} \mathrm{C}$ in $5 \%$ (v/v) $\mathrm{CO}_{2}$ in humidified air for $1 \mathrm{~h}$, and the oocytes were fertilized with a $25-\mu \mathrm{l}$ spermatozoa suspension $\left(\sim 1 \times 10^{6}\right.$ spermatozoa/ml). Approximately $18 \mathrm{~h}$ postinsemination, presumptive zygotes were denuded of cumulus cells by vortexing for $3 \mathrm{~min}$ in $1 \mathrm{ml}$ of synthetic oviduct fluid (SOF) (the SOF stock was modified by adding $10 \%[\mathrm{v} / \mathrm{v}] \mathrm{ECS}, 4 \%$ [v/v] essential amino acids, and $1 \%[\mathrm{v} /$ v] non-essential amino acids). Groups of 25-30 presumptive zygotes were placed in $400 \mu \mathrm{l} \mathrm{SOF}$, overlaid with mineral oil, and cultured at $39^{\circ} \mathrm{C}$ in a humidified atmosphere of $5 \%(\mathrm{v} / \mathrm{v}) \mathrm{CO}_{2}, 5 \%(\mathrm{v} / \mathrm{v}) \mathrm{O}_{2}$, and $90 \%(\mathrm{v} / \mathrm{v}) \mathrm{N}_{2}$.

Parthenogenetic embryos were produced using oocytes that were matured as described above. Twenty-two hours after IVM, oocytes were activated with $5 \mu \mathrm{M}$ ionomycin for $4 \mathrm{~min}$, cultured for $2 \mathrm{~h}$ in IVM medium, and then incubated with $2 \mathrm{mM}$ 6-dimethylaminopurine (6-DMAP) for $4 \mathrm{~h}$.

\section{Apoptosis, Meiotic Stage, and Pronuclear DNA Staining}

The TUNEL procedure was used to detect DNA fragmentation characteristic of apoptosis in COCs and DOs. After IVM, COCs or DOs were washed once in $500 \mu \mathrm{l}$ PBS (10 mM potassium phosphate [pH 7.4], $0.9 \%[\mathrm{w} / \mathrm{v}] \mathrm{NaCl})$ that contained $1 \mathrm{mg} / \mathrm{ml}$ PVP (PBS-PVP). COCs or DOs with intact zona pellucida were fixed in $4 \%(\mathrm{w} / \mathrm{v})$ paraformaldehyde in $\mathrm{PBS}(\mathrm{pH} 7.4)$ for $1 \mathrm{~h}$ at room temperature (RT), washed once in PBS-PVP, and stored in PBS-PVP at $4{ }^{\circ} \mathrm{C}$ until TUNEL analysis. On the day of TUNEL staining, COCs and DOs were permeabilized in 4-well plates that contained $500 \mu \mathrm{l}$ of permeabilization solution $(0.5 \%$ [v/v] Triton X-100, 0.1\% [w/v] sodium citrate) for $1 \mathrm{~h}(\mathrm{DOs})$ or $2 \mathrm{~h}$ (COCs) at RT. Positive and negative controls were incubated in $200 \mu \mathrm{RQ} 1$ RNase-free DNase $(50 \mathrm{U} / \mathrm{ml})$ at $37^{\circ} \mathrm{C}$ for $1 \mathrm{~h}$. Both the COCs and DOs were washed in PBS-PVP and incubated in a $25-\mu 1$ drop of TUNEL reaction mixture, which contained FITC-conjugated dUTP and terminal deoxynucleotidyl transferase (as prepared by the manufacturer), for $1 \mathrm{~h}$ at $37^{\circ} \mathrm{C}$ in the dark. Negative controls were incubated in the absence of terminal deoxynucleotidyl

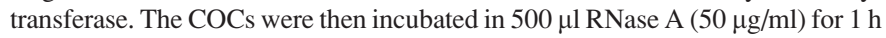
at RT, and counterstained in $200 \mu \mathrm{l}$ propidium iodide (PI) $(0.5 \mu \mathrm{g} / \mathrm{ml})$ for $30 \mathrm{~min}$ at RT. Denuded oocytes were counterstained with DAPI $(1 \mu \mathrm{g} / \mathrm{ml})$ for $30 \mathrm{~min}$ at RT. Both the COCs and DOs were washed three times in PBS-PVP, placed on poly-L-lysine-coated slides, and mounted with Prolong antifade mounting medium. The proportion of apoptotic cumulus cells was determined by counting the total number of nuclei and the total number of TUNEL-labeled nuclei at a total of 10 different sites on the slide. The percentages of apoptotic oocytes were determined by counting the total number of oocytes and total number of TUNELlabeled oocytes. Meiotic stage was determined after DAPI staining by counting the total number of oocytes and the numbers of metaphase I and II oocytes.

Staining of pronuclei was performed to detect the proportions of fertilized, unfertilized, and polyspermic oocyte/zygotes. Eighteen hours after IVF, oocytes/zygotes were denuded of cumulus cells by vortexing in $1 \mathrm{ml}$ PBSPVP and mounted on slides. Oocytes/zygotes were fixed with methanol and glacial acetic acid (3:1) for $24 \mathrm{~h}$ and stained with aceto-orcein for $20 \mathrm{~min}$. The staining solution was washed out by adding $2.5 \%$ glutaraldehyde until the slides were cleared. The slides were sealed with nail polish. Zygotes with two pronuclei and cleaved embryos were considered to be normally fertilized. Oocytes with more than two pronuclei or more than one penetrated sperm head were considered to be polyspermic, and oocytes without a penetrated sperm head were considered to be unfertilized.

COCs and DOs were analyzed using the Zeiss Axiovert $200 \mathrm{M}$ epifluorescence microscope with Zeiss filter sets numbers 9 (FITC/TUNEL), 15 (Texas Red/PI), 2 (DAPI), and 25 (triple band-pass filter for FITC, Texas Red/PI, and DAPI). Representative COCs were additionally analyzed using a confocal laser scanning microscope (LSM 510 Meta; Zeiss, Germany) equipped with a $20 \times$ Plan-NeoFluar objective (Na 0.5). Fluorescein (TUNEL staining) was excited at $488 \mathrm{~nm}$ and PI was excited at $543 \mathrm{~nm}$. The resulting fluorescence emissions were collected through long-pass emission filters at 505 $\mathrm{nm}$ (TUNEL) and $560 \mathrm{~nm}(\mathrm{PI})$.

\section{Generation of Standards for RT-qPCR}

The amplification primers (Table 1) were designed using the software Primer Express 2 and based on sequences deposited in GenBank. Plasmids were produced according to procedures described previously [5]. The cloned plasmids were isolated using the QIAprep Spin Mini Kit according to the manufacturers instructions. Linearized plasmids with the sequence of interest were diluted to one million copies/ $\mu$ l. In order to confirm plasmid identity, the PCR products were subjected to sequence analysis (Laboratory for Functional Genome Analysis - LAFUGA, Munich, Germany).

\section{Isolation of RNA and Reverse Transcription}

Total RNA samples were isolated from individual oocytes and their cumulus cells, respectively. TriZol reagent $(500 \mu \mathrm{l})$ was added to each tube, followed by vortexing for $15 \mathrm{sec}$ to homogenize the samples. Each sample was centrifuged at $11900 \times g$ for $10 \mathrm{~min}$ at $4^{\circ} \mathrm{C}$, and the supernatant $(450 \mu \mathrm{l})$ was mixed with $90 \mu \mathrm{l}$ chloroform in a new tube, vortexed, and incubated for $10 \mathrm{~min}$ at RT. Following a second centrifugation step, the top phase $(250 \mu \mathrm{l})$ was transferred to a new tube and gently mixed with $2 \mu \mathrm{l}$ of glycogen and one volume of $100 \%$ isopropanol and incubated for $10 \mathrm{~min}$ at RT. The samples were centrifuged as described above. The pellet was washed in $500 \mu \mathrm{l}$ of $75 \%$ ethanol and centrifuged for $5 \mathrm{~min}$. The pellet was air-dried, resuspended in 20.5 $\mu \mathrm{l}$ nuclease-free water, heated for $10 \mathrm{~min}$ at $55^{\circ} \mathrm{C}$, and then chilled on ice. A DNase digestion step was performed using $2.5 \mu \mathrm{l}$ DNase digestion buffer and 1 $\mu \mathrm{l}$ DNase $(1 \mathrm{IU} / \mu \mathrm{l})$ at $25^{\circ} \mathrm{C}$ for $15 \mathrm{~min}$. DNase was inactivated with $1 \mu \mathrm{EDTA}$ $(25 \mathrm{mM})$ and by denaturation at $65^{\circ} \mathrm{C}$ for $10 \mathrm{~min}$. 
TABLE 1. Amplification primers used in this study.

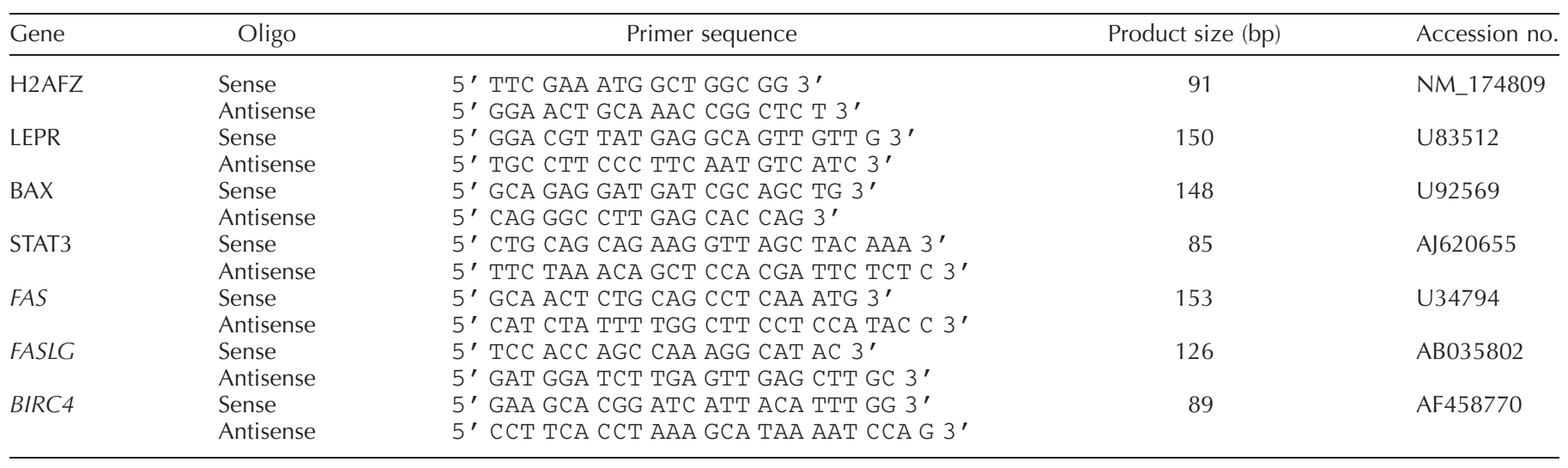

For reverse transcription, $2.5 \mu \mathrm{l}$ random hexamer primers $(3 \mu \mathrm{g} / \mu \mathrm{l}), 2.5 \mu \mathrm{l}$ dNTPs $(10 \mathrm{mM})$, and $1.75 \mu \mathrm{l}$ water were added to the samples, and the mixtures were incubated for $5 \mathrm{~min}$ at $65^{\circ} \mathrm{C}$ and then chilled on ice. The samples were subjected to a short centrifugation step and incubated with $10 \mu \mathrm{l} 5 \times$ transcription buffer, $5 \mu \mathrm{l}$ dithiothreitol $(0.1 \mathrm{M})$, and $2.5 \mu \mathrm{l}$ RNase inhibitor (40 $\mathrm{IU} / \mu \mathrm{l})$ for $10 \mathrm{~min}$ at $25^{\circ} \mathrm{C}$. This was followed by a 2 -min incubation step at $42^{\circ} \mathrm{C}$ and the addition of $0.75 \mu \mathrm{l}$ of Superscript II $(200 \mathrm{IU} / \mu \mathrm{l})$. The reverse transcription reaction was carried out for $60 \mathrm{~min}$ at $42^{\circ} \mathrm{C}$ and terminated by incubating the samples for $15 \mathrm{~min}$ at $70^{\circ} \mathrm{C}$.

\section{Quantitative PCR (qPCR)}

Quantitative PCR was performed using the Real-Time PCR ABI PRISM 7000 sequence detector system (SDS) and SybrGreen as a double-stranded DNA-specific fluorescent dye. The amplification mixes contained $2 \mu \mathrm{cDNA}$, $12.5 \mu \mathrm{l}$ SybrGreen PCR Mix, $0.25 \mu \mathrm{l}$ uracil N-glycosylase $(1 \mathrm{IU} / \mu \mathrm{l}), 1.5 \mu \mathrm{l}$ primer $(5 \mu \mathrm{M})$, and $7.25 \mu \mathrm{l}$ water. The ABI PRISM 7000 SDS system was programmed to start with uracil $\mathrm{N}$-glycosylase activation for $2 \mathrm{~min}$ at $50^{\circ} \mathrm{C}$. The program continued with $10 \mathrm{~min}$ at $95^{\circ} \mathrm{C}$ and 40 cycles of DNA denaturation $(15$ $\mathrm{sec}$ at $\left.95^{\circ} \mathrm{C}\right)$, primer annealing $\left(30 \mathrm{sec}\right.$ at $\left.60^{\circ} \mathrm{C}\right)$, and elongation $(30 \mathrm{sec}$ at $72^{\circ} \mathrm{C}$ ). Serial dilutions of the plasmids were used to establish a standard curve for each gene of interest. Each qPCR was run in triplicate. The transcript copy numbers of $L E P R$, STAT3, BAX (encodes the BCL2-associated X protein), FAS, $F A S L G$, and BIRC4 (encodes baculoviral inhibitor of apoptosis protein repeatcontaining 4, also known as XIAP) were calculated using the standard curve method with determination of PCR amplification efficiency, and normalized for the histone 2A (H2AFZ) transcript levels. The transcript levels in the control group $(0 \mathrm{ng} / \mathrm{ml}$ leptin) were set at 1 and the data in the treatment groups were calibrated accordingly.

\section{Experimental Design}

Figure 1 shows a schematic representation of the experiments used in the studies described below.

\section{Effects of Leptin on Meiotic Progression and Apoptosis of COCs}

Cumulus-oocyte complexes were matured in serum-free maturation medium that contained 0,1 or $10 \mathrm{ng} / \mathrm{ml}$ recombinant human leptin or maturation medium that contained 10\% (v/v) ECS as a positive control. In Experiment 1, COCs were denuded after maturation by repeated pipetting in a 50- $\mu$ l droplet of PBS that contained $4 \mathrm{mg} / \mathrm{ml}$ BSA (PBS-BSA). Denuded oocytes were examined under a stereomicroscope (Stemi DV6, Zeiss) for the presence of the first polar body (PB). Denuded oocytes from three IVM replicates (54-87 DOs per treatment) were harvested following PB evaluation, washed in PBSPVP, and fixed in 4\% (w/v) paraformaldehyde for TUNEL and DAPI staining. In Experiment 2, COCs were matured as described above. After maturation, the COCs were fixed in $4 \%(w / v)$ paraformaldehyde for TUNEL analysis.

\section{Effects of Leptin on Meiotic Progression, Fertilization, and Developmental Competence of Cumulus-Enclosed and Denuded Oocytes}

In the series of experiments described below, COCs and DOs were matured in serum-free maturation medium that contained 0 or $10 \mathrm{ng} / \mathrm{ml}$ recombinant human leptin. Experiment 3 was conducted to determine the proportion of oocytes with extruded PBs. Immediately after IVM, COCs were denuded by repeated pipetting in a 50- $\mu$ droplet of PBS-BSA, in order to allow PB visualization under the stereomicroscope (Stemi DV6, Zeiss). The DOs were washed under the same conditions. In Experiment 4, COCs and DOs were subjected to IVM and fertilization as described above. The proportions of fertilized, unfertilized, and polyspermic oocytes were determined by the staining of pronuclei. In Experiments 5-7, the proportions of oocytes that cleaved and developed to the blastocyst stage were assessed at Days 3 and 8 post-insemination, respectively. Matured COCs and DOs were in vitrofertilized (Experiment 5), had their cumulus cells removed before fertilization (Experiment 6) or underwent parthenogenetic activation (Experiment 7).

\section{Effects of Leptin on Levels of Specific Transcripts in Cumulus Cells and Oocytes}

COCs were matured in serum-free maturation medium that contained 0,1 or $10 \mathrm{ng} / \mathrm{ml}$ recombinant human leptin. After maturation, each COC was individually denuded by repeated pipetting in a $50-\mu 1$ droplet of PBS-BSA. Each fully denuded oocyte (in $5 \mu \mathrm{l}$ ) and its respective cumulus cells (in $50 \mu \mathrm{l}$ ) were harvested separately, stored in microcentrifuge tubes that contained $15 \mu \mathrm{l}$ (DOs) and $50 \mu \mathrm{l}$ (CCs) of RNAlater, and kept at $-80^{\circ} \mathrm{C}$ until RNA extraction. The transcript levels of the genes H2AFZ, LEPR, STAT3, BAX, BIRC4, FASLG, and FAS were determined by RT-qPCR analysis.

\section{Statistical Analysis}

The data were analyzed by least-squares analysis of variance. Dependent variables were the percentage of apoptotic cumulus cells, percentage of apoptotic oocytes, percentage of oocytes with extruded PB, percentages of MI and MII oocytes, percentages of fertilized, unfertilized, cleaved, and polyspermic oocytes, percentage of oocytes that developed to the blastocyst stage, mRNA copy number normalized to the housekeeping gene $H 2 A F Z$, and the arcsin of the percentage variables. Independent variables varied according to the experimental design and included treatment, oocyte type (COCs and DOs), and replicate. The mathematical model included the main effects and all the interactions. Two analyses were performed, i.e., the General Linear Models (GLM) procedure of SAS (SAS Institute, Cary, NC), in which replicate (i.e., the day of IVP procedure) was considered to be a fixed variable, and the Mixed Models procedure of SAS, in which replicate was considered to be a random variable. The probability values were similar for the two methods. The probability values reported herein were obtained by the GLM procedure. Percentage data were analyzed without transformation and after arcsin transformation to correct for non-normal distribution. Orthogonal contrasts and the pdiff procedure of SAS were performed where appropriate to determine differences between the various levels of a treatment.

\section{RESULTS}

\section{Effects of Leptin on Meiotic Progression and Apoptosis of COCs}

The aim of these experiments was to determine whether leptin supplementation affects nuclear maturation and the incidence of apoptosis in oocytes and cumulus cells. The 


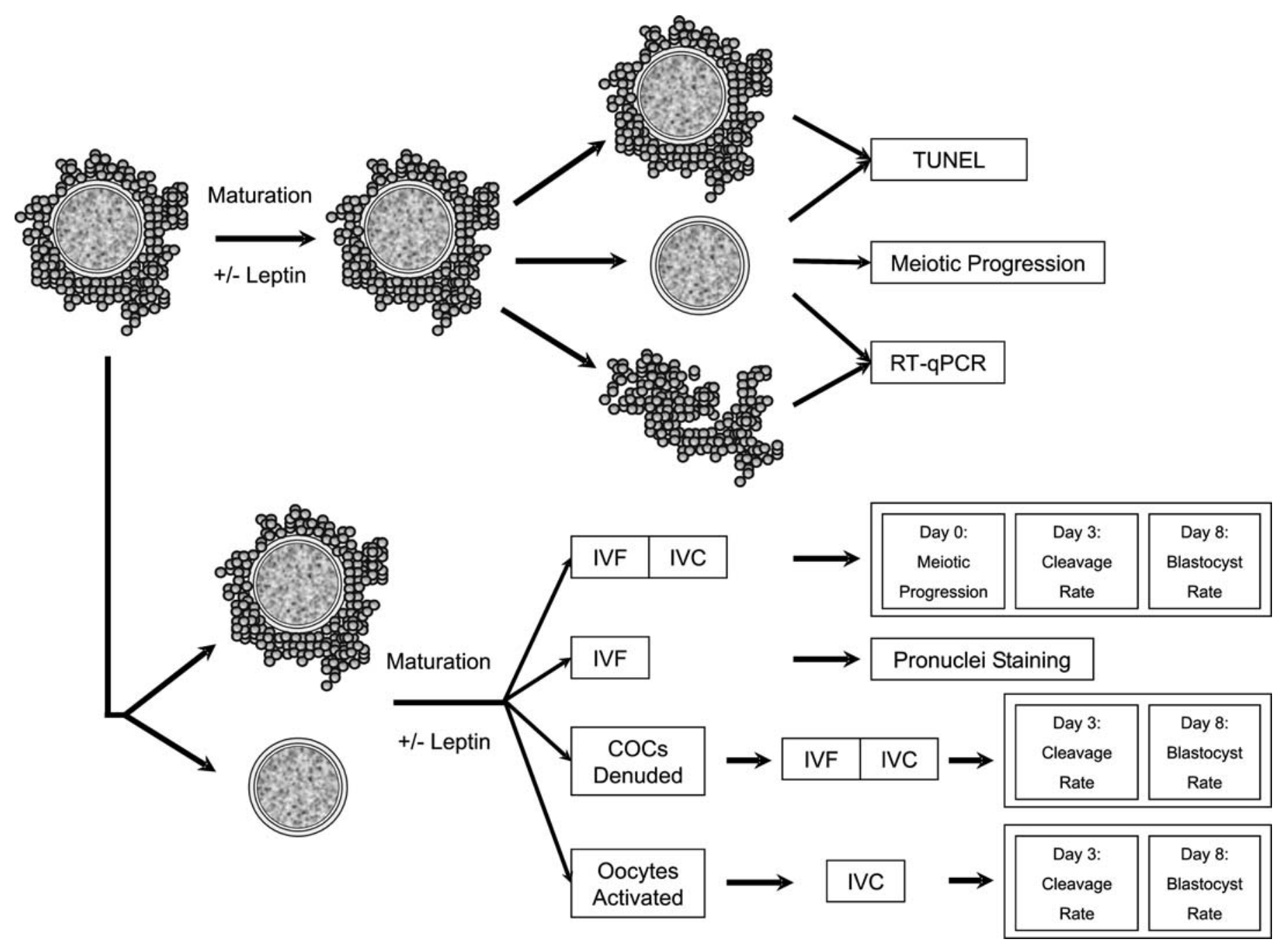

FIG. 1. Schematic representation of the experimental design used in this study.

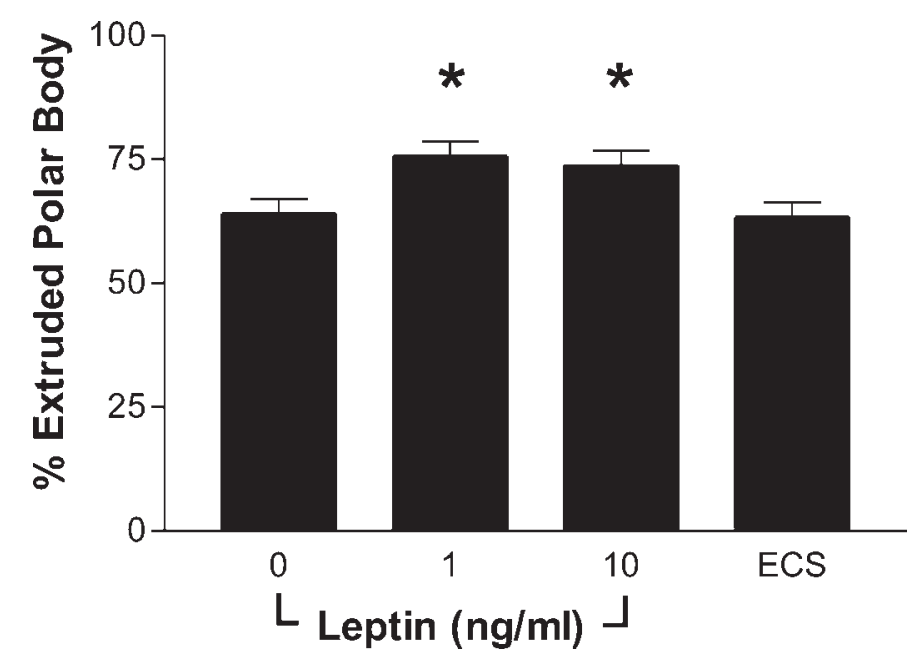

FIG. 2. Effect of leptin during maturation of bovine oocytes on the proportion of oocytes with extruded polar body. The results shown are least-squares means \pm SEM of eight replicates using 260-292 oocytes per treatment. Significant differences $(P<0.05)$ from the control group $(0 \mathrm{ng} /$ $\mathrm{ml}$ leptin) are indicated by single asterisks.

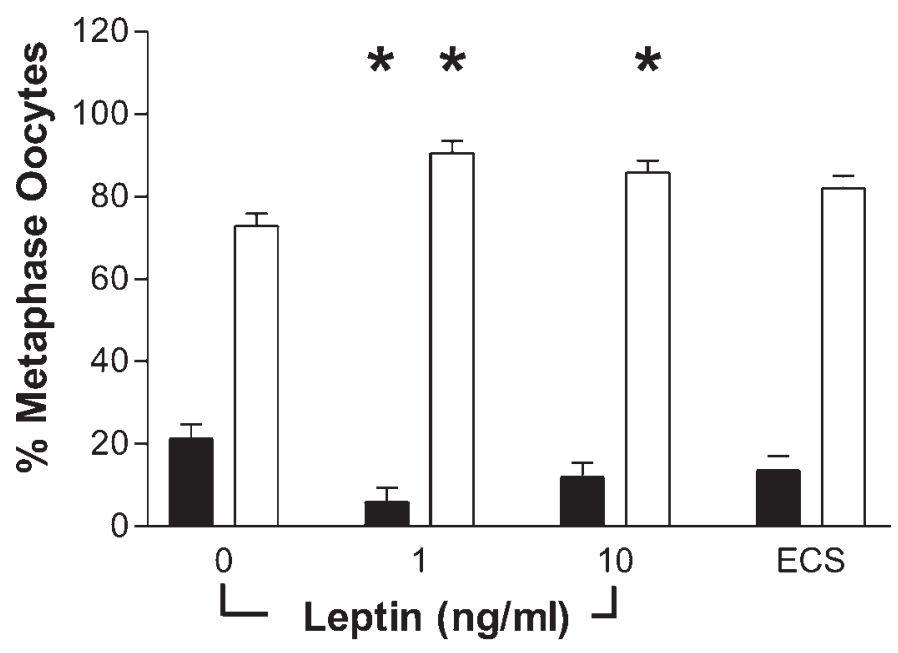

FIG. 3. Effect of leptin during maturation of bovine oocytes on the proportions of metaphase I (black bars) and II (white bars) oocytes. The results shown are least-squares means \pm SEM of three replicates using 54 87 oocytes per treatment. Significant differences $(P<0.05)$ from the control group $(0 \mathrm{ng} / \mathrm{ml}$ leptin) are indicated by single asterisks. 

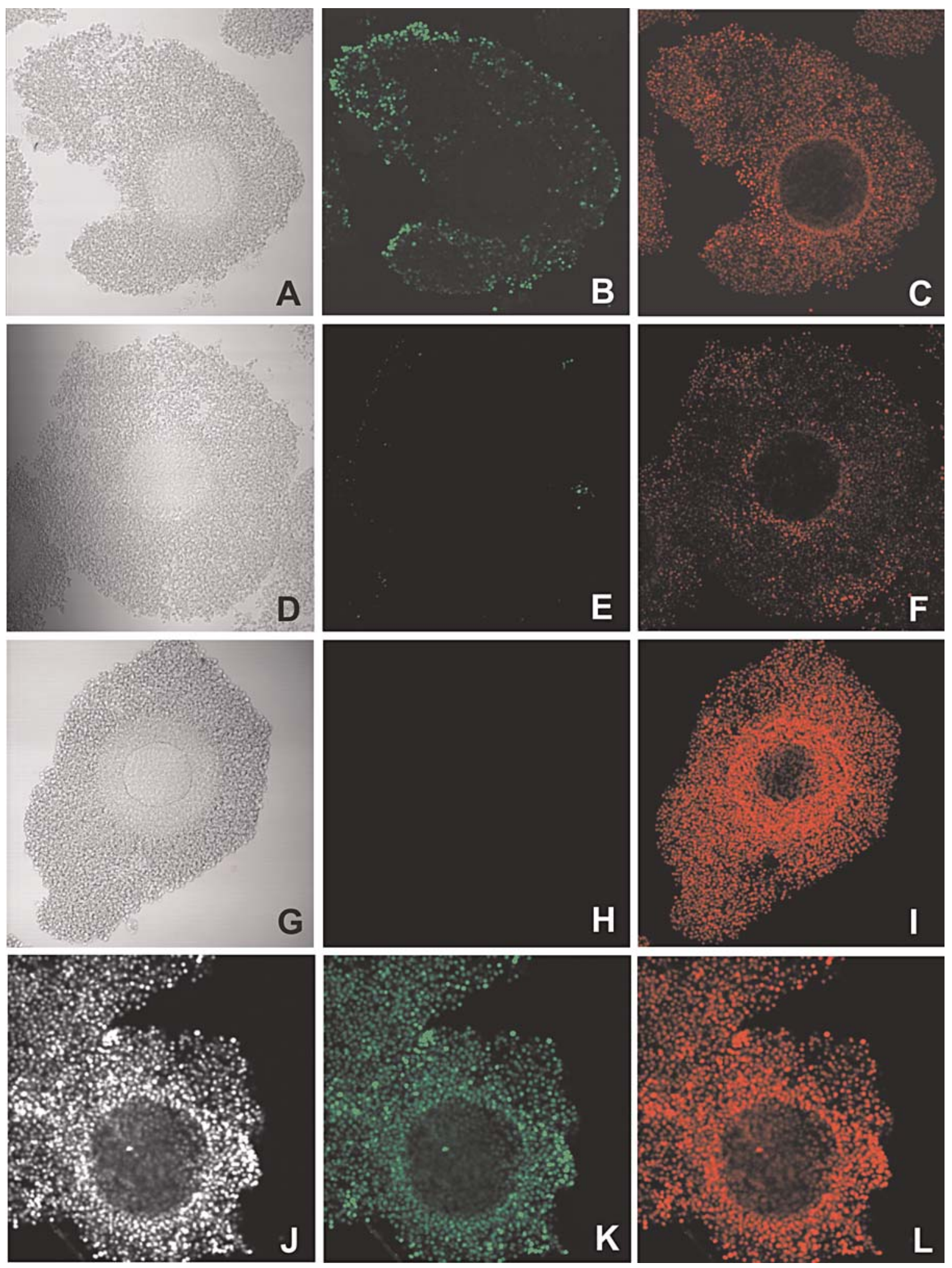

FIG. 4. Representative confocal images illustrating the frequency of apoptotic nuclei (green) in bovine COCs, as revealed by TUNEL staining. Cumulusoocyte complexes were labeled with FITC-conjugated dUTP (green channel; B, E, H, K) and propidium iodide (red channel; C, F, I, L). Bright-field acquisitions are shown in $\mathbf{A}, \mathbf{D}, \mathbf{G}$ and $\mathbf{~ J . ~ A - C ) ~ C o n t r o l ~ C O C ~ m a t u r e d ~ w i t h o u t ~ l e p t i n . ~ D - F ~ a n d ~} \mathbf{G}-\mathbf{I}$ ) COCs matured in the presence of $1 \mathrm{and} 10 \mathrm{ng} / \mathrm{ml}$ leptin, respectively. J-L) Positive control COC treated with DNase before TUNEL staining. Optical sections (thickness of $\sim 4 \mu \mathrm{m}$ ) were obtained using a Zeiss LSM 510 Meta microscope coupled to a $20 \times$ objective.

addition of leptin during the maturation of bovine oocytes clearly stimulated meiotic progression: the proportion of oocytes with extruded first PB was increased $(P<0.05)$ by 1 and $10 \mathrm{ng} / \mathrm{ml}$ leptin (Fig. 2). Moreover, DAPI staining demonstrated that $1 \mathrm{ng} / \mathrm{ml}$ leptin reduced $(P<0.05)$ the proportion of oocytes at metaphase I, while 1 and $10 \mathrm{ng} / \mathrm{ml}$ leptin increased $(P<0.05)$ the proportion of oocytes at metaphase II (Fig. 3). There was no effect of ECS on the 


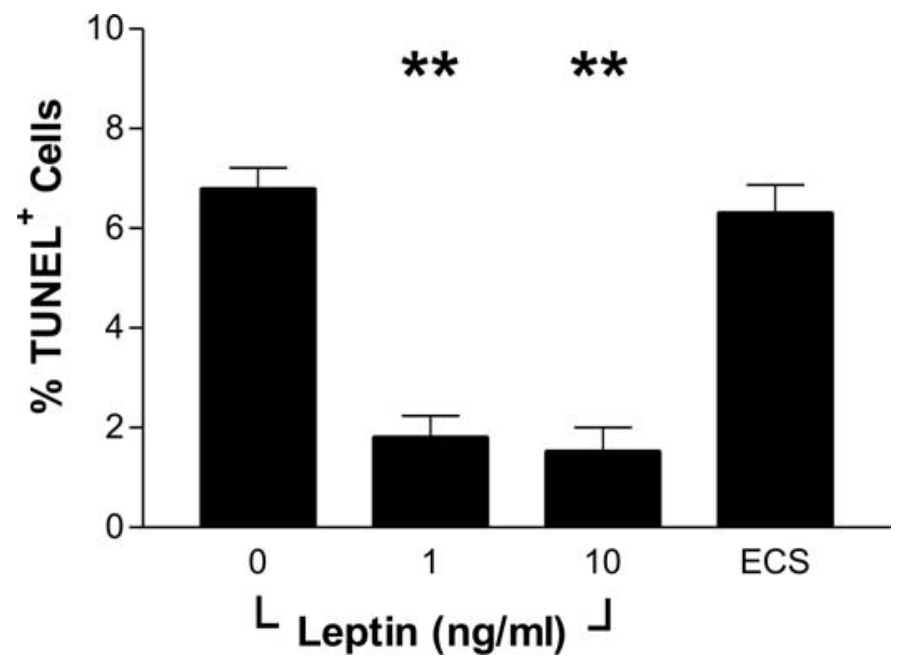

FIG. 5. Effect of leptin during maturation of bovine oocytes on the proportion of TUNEL-positive cumulus cells. The results shown are leastsquares means \pm SEM of five replicates using 67-103 COCs per treatment. Significant differences $(P<0.001)$ from the control group $(0$ $\mathrm{ng} / \mathrm{ml}$ leptin) are indicated by double asterisks.

proportions of extruded PBs (Fig. 2) or metaphase oocytes (Fig. 3).

Figure 4 displays representative confocal images of bovine COCs that were subjected to TUNEL analysis. A control COC matured in the absence of leptin is shown in panels A-C. Panels D-F and G-H show COCs that were matured in the presence of 1 and $10 \mathrm{ng} / \mathrm{ml} \mathrm{leptin,} \mathrm{respectively.} \mathrm{Note} \mathrm{that} \mathrm{leptin-treated}$ COCs had reduced proportions of TUNEL-positive cumulus cells (green color). Both leptin concentrations (1 and $10 \mathrm{ng} / \mathrm{ml}$ ) markedly reduced $(P<0.001)$ the proportion of TUNELpositive cumulus cells (Fig. 5). There was no effect of ECS on this parameter (Fig. 5). In contrast to the findings in cumulus cells, leptin had no effect on the proportion of apoptotic oocytes as determined by TUNEL staining. The proportion of TUNEL-positive oocytes $(0-4.6 \%)$ was very low regardless of leptin or ECS supplementation.

Effects of Leptin on Meiotic Progression, Fertilization, and Developmental Competence of Cumulus-Enclosed and Denuded Oocytes

These experiments were designed as a $2 \times 2$ factorial arrangement of treatments to determine whether the beneficial effect of leptin during oocyte maturation was mediated by cumulus cells. The addition of $10 \mathrm{ng} / \mathrm{ml}$ leptin increased $(P<$ $0.05)$ the proportions of COCs and DOs with extruded PBs regardless of cumulus cells (Fig. 6). There was no leptin $\times$ oocyte-type interaction regarding oocyte meiotic progression. Pronuclei staining demonstrated that the proportion of polyspermic oocytes was not affected by leptin, oocyte type or leptin $\times$ oocyte-type interaction (Fig. 7). Leptin increased $(P$ $<0.05)$ the fertilization rate and decreased $(P<0.05)$ the rate of unfertilized COCs, but not DOs. Even though there was a leptin $\times$ oocyte-type interaction $(P<0.05)$ on the fertilization rate at Day 1 , this type of effect was not observed for the proportions of oocytes that cleaved at Day 3 postinsemination (Experiments 5, 6, and 7; data not shown). However, Experiments $5(P<0.05), 6(P<0.05)$, and $7(P<0.001)$ showed a consistent leptin $\times$ oocyte-type interaction on the proportion of oocytes that developed to the blastocyst stage at Day 8 postinsemination. In these studies, leptin acted on COCs

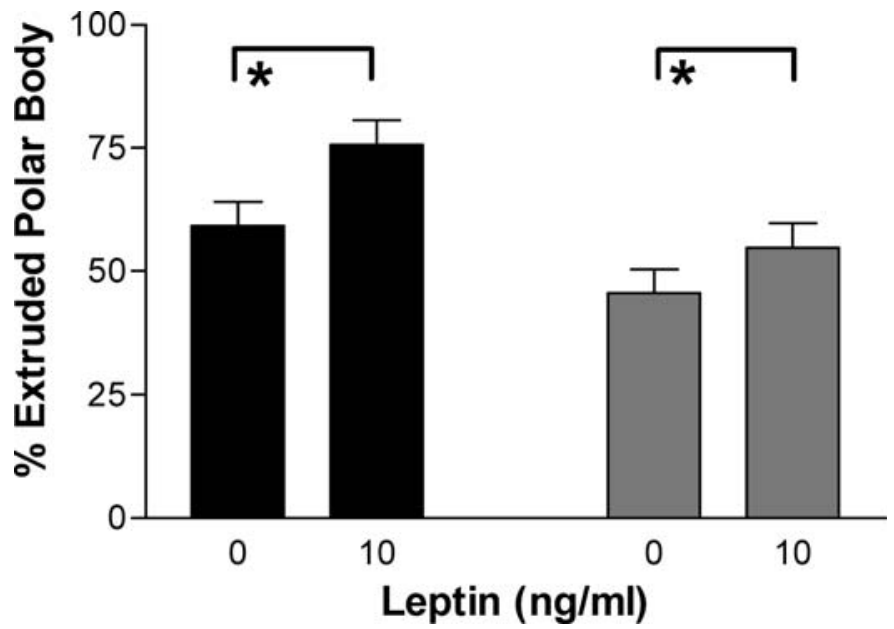

FIG. 6. Effect of leptin and cumulus cells on the percentage of COCs (black bars) and DOs (grey bars) that extruded the first polar body. The results shown are least-squares means \pm SEM of 7 replicates using 219257 oocytes per treatment. Significant differences $(P<0.05)$ between treatments are indicated by single asterisks.

(but not on DOs) to increase $(P<0.05)$ development to the blastocyst stage (Fig. 8). Leptin exerted a positive effect during the maturation of bovine COCs to enhance developmental capacity following the fertilization of cumulus-enclosed oocytes (Experiment 5; Fig 8A), fertilization of cumulus-free oocytes (Experiment 6; Fig 8B), and parthenogenetic activation of oocytes (Experiment 7; Fig 8C). The lack of leptin effect on DOs was not due to either a requirement for cumulus cells during fertilization or an increase in the number of polyspemic oocytes.

\section{Effects of Leptin on Levels of Specific Transcripts in Cumulus Cells and Oocytes}

The mRNA levels of H2AFZ, LEPR, STAT3, and the apoptosis-associated genes BAX, BIRC4,FAS, and FASLG were determined by RT-qPCR, to evaluate whether leptin supplementation during oocyte maturation affects the expression of these selected genes in matured oocytes and cumulus

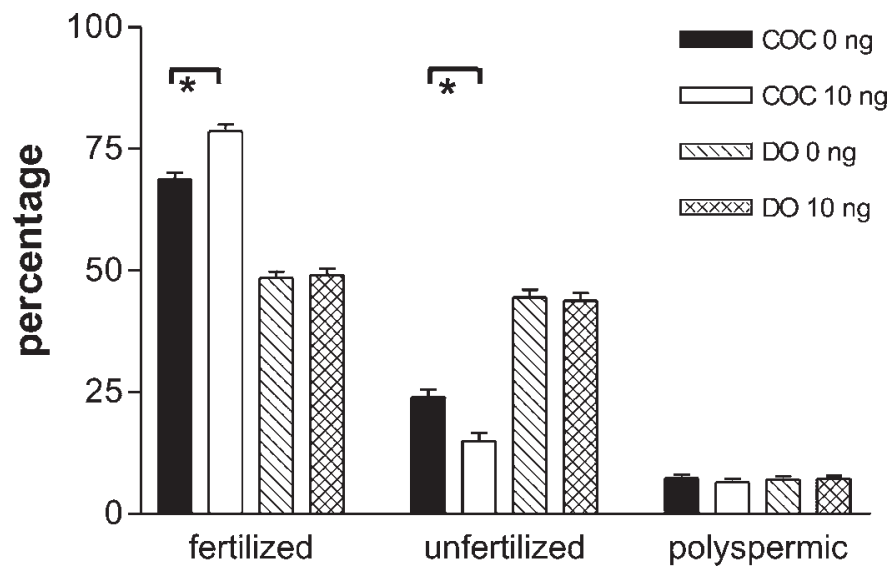

FIG. 7. Effects of leptin and cumulus cells on the proportions of fertilized, unfertilized, and polyspermic oocytes/zygotes. The results shown are least-square means \pm SEM of three replicates using 201-214 oocytes per treatment. Significant differences $(P<0.05)$ between treatments are indicated by single asterisks. 


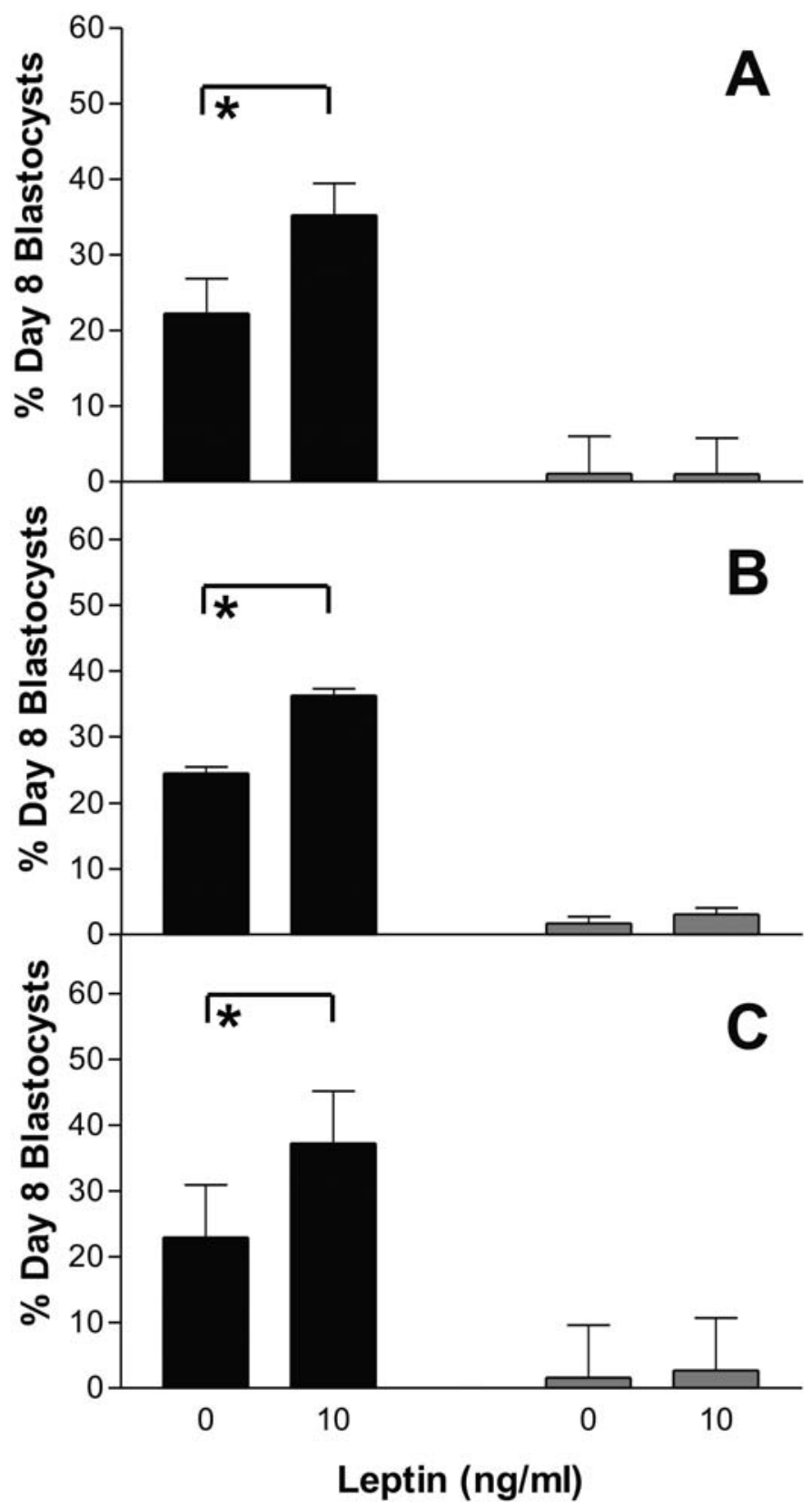

FIG. 8. Effects of leptin and cumulus cells on the proportions of COCs (black bars) and DOs (grey bars) that develop to the blastocyst stage at Day 8 postinsemination. The results shown are least-squares means \pm SEM. In vitro-matured COCs and DOs were fertilized (A; Experiment 5 was replicated 9 times using 308-342 oocytes per treatment), had their cumulus cells removed before fertilization (B; Experiment 6 was replicated 3 times using 230-240 oocytes per treatment), or were pathenogenetically activated (C; Experiment 7 was replicated 4 times using 260-280 oocytes per treatment). Significant differences $(P<0.05)$ between treatments are indicated by single asterisks.

cells. The addition of 1 and $10 \mathrm{ng} / \mathrm{ml}$ leptin during oocyte maturation did not affect the expression of the housekeeping gene $H 2 A F Z$ in matured oocytes or cumulus cells. There was no effect of these leptin doses on LEPR, BAX, and BIRC4 expression in oocytes. FAS mRNA abundance in oocytes was increased by $1 \mathrm{ng} / \mathrm{ml}(P<0.05)$ and $10 \mathrm{ng} / \mathrm{ml}(P<0.001)$ leptin, whereas FASLG and STAT3 transcripts were only increased $(P<0.05)$ by the higher dose of $10 \mathrm{ng} / \mathrm{ml}$ leptin (Fig. 9).
In cumulus cells, the mRNA levels of LEPR, STAT3, BAX, $B I R C 4$, and $F A S$ were increased by $1 \mathrm{ng} / \mathrm{ml}(P<0.001)$ and 10 $\mathrm{ng} / \mathrm{ml}(P<0.001)$ leptin (Fig. 9). Notably, the $B A X$ mRNA levels in cumulus cells from both leptin-treated COC groups were about twofold higher, whereas the BIRC4 transcript levels were about fourfold higher as compared to the control group. The levels of FASLG transcripts in cumulus cells were not affected by leptin treatment (Fig. 9).

\section{DISCUSSION}

The processes of meiotic maturation and acquisition of developmental competence determine the ability of the oocyte to undergo successful fertilization, cleavage, and embryonic development. These important steps are dependent upon a variety of factors that lead to proper nuclear and cytoplasmic maturation [14]. The present study demonstrates that physiological leptin doses enhance both oocyte maturation and differentially regulated gene expression in oocytes and cumulus cells. The leptin concentrations of 1 and $10 \mathrm{ng} / \mathrm{ml}$ used in this study represent the physiological serum leptin levels found in periparturient [20,21] and cyclic cows [22]. Moreover, we have previously demonstrated that these leptin concentrations enhance the developmental capacity of oocytes, while higher doses have no effect [5].

Oocyte meiotic maturation is a complex process that involves germinal vesicle breakdown, chromosome condensation and segregation, formation of the metaphase plate, completion of meiosis I, extrusion of the first PB, and arrest at metaphase II. The addition of leptin during the maturation of bovine COCs increased PB extrusion and the proportion of oocytes that reached the metaphase II stage. The presence of LEPR mRNA in both oocytes and cumulus cells suggests that both cell types are responsive to leptin. The present study demonstrates that stimulation of first PB extrusion by leptin is independent of cumulus cells, which suggests a direct effect on the oocyte. It is possible that leptin promotes rearrangement of cytoskeletal elements [23, 24], such as microfilaments, which are implicated in the migration of the metaphase I spindle to the plasma membrane and extrusion of the first PB [24], as well as microtubules that are involved in meiotic division [25].

It is well known that oocyte developmental potential is a reflection of proper cytoplasmic maturation. Even though most bovine oocytes resume meiosis and progress to metaphase II following IVM [26], cytoplasmic maturation in vitro is generally compromised, leading to low rates of development. We have previously demonstrated that leptin exerts long-term effects in enhancing the preimplantation development of leptintreated oocytes [5]. In agreement with these results, the current study shows that leptin acts in cumulus-enclosed oocytes to stimulate subsequent development to the blastocyst stage. However, leptin did not stimulate the development of DOs, demonstrating a role for cumulus cells in mediating leptin effects. Leptin may influence the synthesis and release of cumulus cell-derived factors, which reach the oocyte through gap junction coupling and the extracellular environment. It is possible that leptin treatment converts cumulus cells into a population of cells that is more responsive to leptin than the oocyte itself. Although LEPR mRNA was expressed in both oocytes and cumulus cells, maturation of bovine COCs in the presence of leptin increased $L E P R$ transcript abundance in cumulus cells but not in oocytes. Similarly, leptin caused a greater increase in the STAT3 transcript level in cumulus cells than in oocytes.

Taken together, these results demonstrate that leptin enhances the developmental potential of oocytes via cumulus 


\section{A) LEPR}

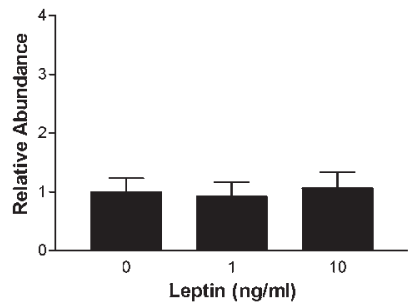

B) STAT3

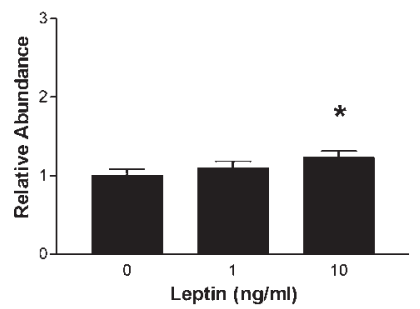

C) $B A X$

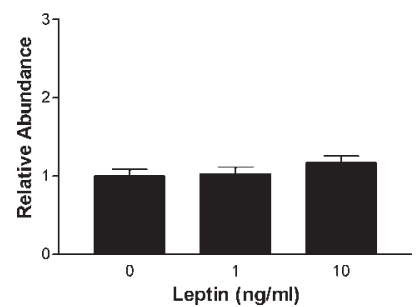

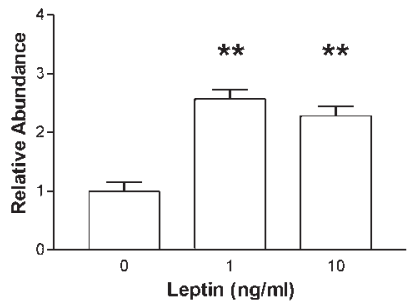
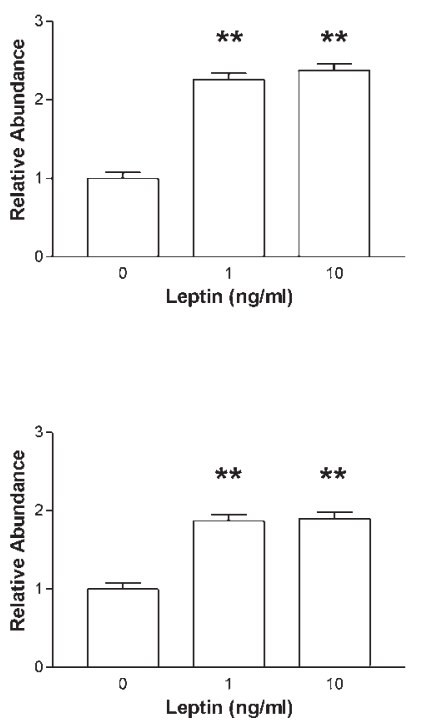

\section{D) BIRC4}
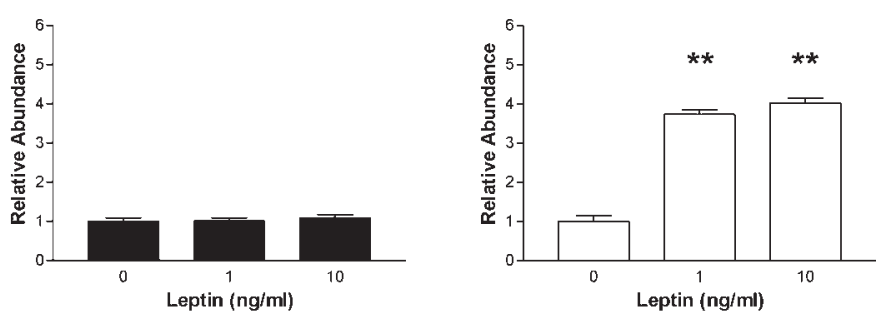

E) FAS
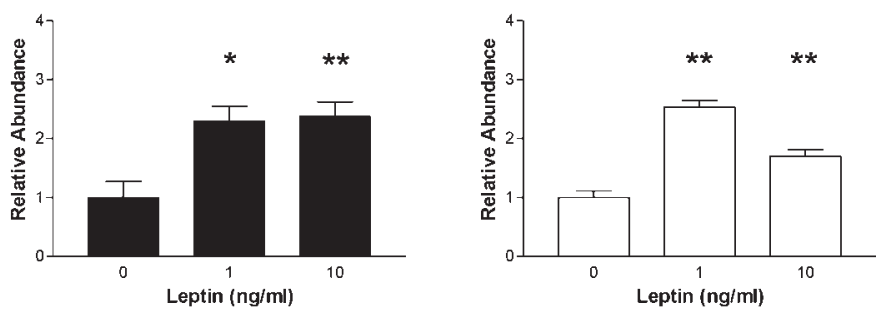

F) FASLG

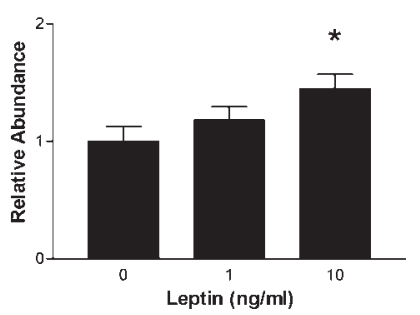

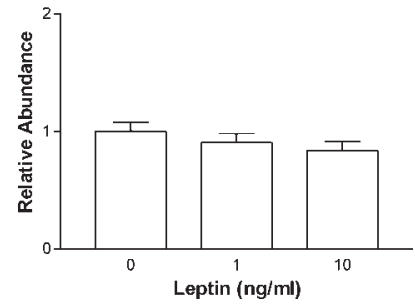

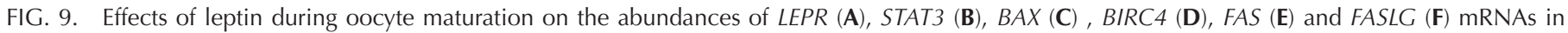

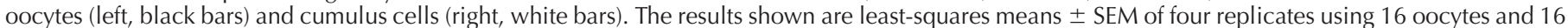

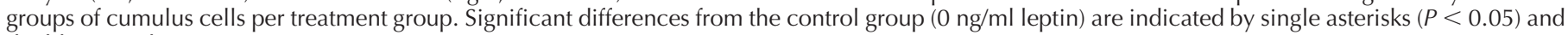
double asterisks $(P<0.001)$.

cell-dependent mechanisms. This was consistently observed in different experimental models: fertilization of cumulusenclosed oocytes, fertilization of cumulus-free oocytes, and parthenogenetic oocyte activation. The finding that leptin enhanced the maturation of COCs even when cumulus cells were removed after maturation indicates that the lack of cumulus cells during fertilization does not override any potential positive effect of leptin on DOs. The use of parthenogenetic-activated oocytes provides a model in which the confounding effects of cumulus cell requirement during fertilization were excluded.

Leptin had no effect on blastocyst development of DOs, while it enhanced blastocyst formation after treatment of COCs. Indeed, removal of cumulus cells before oocyte maturation had a deleterious effect on subsequent blastocyst development, which was not rescued by leptin supplementation.

Our results indicate that neither leptin nor oocyte type influence the proportion of polyspermic oocytes. Therefore, the inhibitory effect of cumulus cell removal on oocyte developmental capacity is not due to polyspermy.

Several studies have demonstrated the occurrence of apoptosis in human $[27,28]$ and bovine cumulus cells [17, $29,30]$, while others have reported a lack of apoptotic cumulus cells in rats [31], pigs [32], and cattle [33]. In the present study, cumulus cell apoptosis was observed in COCs that were matured in the presence or absence of serum. The addition of 1 and $10 \mathrm{ng} / \mathrm{ml}$ leptin to serum-free maturation medium reduced the proportion of apoptotic cumulus cells. Leptin acted as a survival factor that rescued cumulus cells from committing to the apoptotic program. The mechanisms by which leptin suppresses the apoptotic machinery involves complex changes in the gene expression of cumulus cells. Leptin upregulated the transcript levels of the pro-apoptotic genes FAS and $B A X$. These genes are implicated in the death receptor and mitochondrial pathways of caspase activation. While FAS activation stimulates protein-protein interactions at the cytoplasmic death domain of FAS leading to caspase activation, BAX triggers cytochrome $\mathrm{c}$ release from the mitochondria and caspase activation [34]. However, leptin supplementation increased the transcript level of the potent antiapoptotic gene BIRC4, which encodes an endogenous inhibitor of caspases [35]. The inhibitory effect of BIRC4 is exerted downstream to FAS and BAX. It is known that the leptin receptor stimulates the MAPK3/1 pathway [13] which can activate the antiapoptotic gene BIRC4 [36]. This may explain the fourfold increase in BIRC4 mRNA and the reduced proportion of apoptotic cumulus cells in leptin-treated COCs.

Apoptosis plays an important role in mammalian development as a quality control mechanism to eliminate cells that are damaged, nonfunctional, abnormal or misplaced [37]. The incidence of cumulus cell apoptosis has been used as a predictor of oocyte quality [27], and it has been found to be negatively correlated with the developmental competence of oocytes [38]. Interestingly, this type of correlation was not 
observed in FAS-induced apoptosis, possibly because in this study, FAS increased apoptosis in the periphery of the cumulus cells, while the corona radiata showed no signs of apoptosis and remained tightly attached to the oocyte [18]. In the current study, leptin supplementation during oocyte maturation reduced the proportion of apoptotic cumulus cells and enhanced subsequent preimplantation development. It is possible that the inhibitory effect of leptin on cumulus cell apoptosis enhances subsequent blastocyst development. However, further experiments using caspase inhibitors are required in order to show conclusively that the stimulatory effect of leptin on oocyte developmental capacity is mediated by a reduction in cumulus cell apoptosis.

In contrast to cumulus cells, leptin had no effect on the proportion of apoptotic oocytes. The incidence of spontaneous oocyte apoptosis was very low, regardless of leptin treatment. This resistance of oocytes to apoptosis during IVM may be related to the balance between proapoptotic and antiapoptotic molecules. The fate of the cell depends on many factors, including the relative ratio and competitive dimerization between proapoptotic and the antiapoptotic proteins, which determines in large part whether the cell will commit to death following an apoptosis-inducing stimulus [39]. Transcripts of the apoptosis-related genes $B A X$ and $B I R C 4$ were detected in bovine oocytes, but their expression was not influenced by leptin treatment. In contrast, leptin increased the oocyte transcript levels of the proapoptotic genes FAS and FASLG. However, the bovine oocyte is resistant to FAS-induced apoptosis due to an incomplete FAS signaling pathway. It has been demonstrated that the bovine oocyte lacks both FASLG protein and active caspases despite mRNA expression $[18,40]$.

The developmental potential of oocytes matured in vitro is reduced compared to oocytes matured in vivo [41]. In order to characterize the specific requirements for bovine oocyte maturation, it is necessary to establish a serum-free oocyte maturation medium. In the current study, the percentages of oocytes that extruded the first $\mathrm{PB}$ and that reached the metaphase II stage, and the percentage of TUNEL-positive cumulus cells were not different between COCs that were matured in serum-free medium or medium supplemented with $10 \%$ serum. Other studies have reported that blastocysts are successfully produced from oocytes matured in serum-free medium [42-44]. However, blastocysts derived from oocytes matured under serum-free conditions display an increased incidence of apoptosis, which is reversed by the addition of leptin to the serum-free maturation medium [5].

In conclusion, leptin acts directly in the oocyte to enhance meiotic maturation and acts via cumulus cells to enhance oocyte development potential. These beneficial effects are associated with a leptin-induced reduction in cumulus cell apoptosis and differential regulation of apoptosis-associated genes and genes involved in leptin signal transduction.

\section{ACKNOWLEDGMENTS}

The authors thank Tuna Guengoer and Myriam Weppert for their contributions to these studies and the Rinderunion Baden-Württemberg e.V. (Stuttgart, Germany) for donating the semen. The authors are also grateful for the support provided by the Brazilian Research Agency CNPq.

\section{REFERENCES}

1. Gonzalez RR, Caballero-Campo P, Jasper M, Mercader A, Devoto L, Pellicer A, Simon C. Leptin and leptin receptor are expressed in the human endometrium and endometrial leptin secretion is regulated by the human blastocyst. J Clin Endocrinol Metab 2000; 85:4883-4888.

2. Almog B, Gold R, Tajima K, Dantes A, Salim K, Rubinstein M, Barkan D,
Homburg R, Lessing JB, Nevo N, Gertler A, Amsterdam A. Leptin attenuates follicular apoptosis and accelerates the onset of puberty in immature rats. Mol Cell Endocrinol 2001; 183:179-191.

3. Ryan NK, Woodhouse CM, Van der Hoek KH, Gilchrist RB, Armstrong DT, Norman RJ. Expression of leptin and its receptor in the murine ovary: possible role in the regulation of oocyte maturation. Biol Reprod 2002; 66: $1548-1554$

4. Swain JE, Dunn RL, McConnell D, Gonzalez-Martinez J, Smith GD. Direct effects of leptin on mouse reproductive function: regulation of follicular, oocyte, and embryo development. Biol Reprod 2004; 71:14461452.

5. Boelhauve M, Sinowatz F, Wolf E, Paula-Lopes FF. Maturation of bovine oocytes in the presence of leptin improves development and reduces apoptosis of in vitro-produced blastocysts. Biol Reprod 2005; 73:737-744.

6. Craig J, Zhu H, Dyce PW, Petrik J, Li J. Leptin enhances oocyte nuclear and cytoplasmic maturation via the mitogen-activated protein kinase pathway. Endocrinology 2004; 145:5355-5363.

7. Cioffi JA, Van Blerkom J, Antczak M, Shafer A, Wittmer S, Snodgrass HR. The expression of leptin and its receptors in pre-ovulatory human follicles. Mol Hum Reprod 1997; 3:467-472.

8. Antczak M, Van Blerkom J. Oocyte influences on early development: the regulatory proteins leptin and STAT3 are polarized in mouse and human oocytes and differentially distributed within the cells of the preimplantation stage embryo. Mol Hum Reprod 1997; 3:1067-1086.

9. Barroso G, Barrionuevo M, Rao P, Graham L, Danforth D, Huey S, Abuhamad A, Oehninger S. Vascular endothelial growth factor, nitric oxide, and leptin follicular fluid levels correlate negatively with embryo quality in IVF patients. Fertil Steril 1999; 72:1024-1026.

10. Matsuoka T, Tahara M, Yokoi T, Masumoto N, Takeda T, Yamaguchi M, Tasaka K, Kurachi H, Murata Y. Tyrosine phosphorylation of STAT3 by leptin through leptin receptor in mouse metaphase 2 stage oocyte. Biochem Biophys Res Commun 1999; 256:480-484.

11. Kawamura K, Sato N, Fukuda J, Kodama H, Kumagai J, Tanikawa H, Nakamura A, Tanaka T. Leptin promotes the development of mouse preimplantation embryos in vitro. Endocrinology 2002; 143:1922-1931.

12. Cioffi JA, Shafer AW, Zupancic TJ, Smith-Gbur J, Mikhail A, Platika D, Snodgrass HR. Novel B219/OB receptor isoforms: possible role of leptin in hematopoiesis and reproduction. Nat Med 1996; 2:585-589.

13. Fruhbeck G. Intracellular signalling pathways activated by leptin. Biochem J 2006; 393:7-20.

14. Tanghe S, Van Soom A, Nauwynck H, Coryn M, de Kruif A. Minireview: functions of the cumulus oophorus during oocyte maturation, ovulation, and fertilization. Mol Reprod Dev 2002; 61:414-424.

15. Fukui Y, Sakuma Y. Maturation of bovine oocytes cultured in vitro: relation to ovarian activity, follicular size and the presence or absence of cumulus cells. Biol Reprod 1980; 22:669-673.

16. Chian RC, Sirard MA. Effects of cumulus cells and follicle-stimulating hormone during in vitro maturation on parthenogenetic activation of bovine oocytes. Mol Reprod Dev 1995; 42:425-431.

17. Ikeda S, Imai H, Yamada M. Apoptosis in cumulus cells during in vitro maturation of bovine cumulus-enclosed oocytes. Reproduction 2003; 125 : 369-376.

18. Pomar FJ, Ducro-Steverink DW, Hazeleger W, Teerds KJ, Colenbrander B, Bevers MM. Development, DNA fragmentation and cell death in porcine embryos after $24 \mathrm{~h}$ storage under different conditions. Theriogenology 2004; 61:147-158.

19. Porter DA, Harman RM, Cowan RG, Quirk SM. Relationship of Fas ligand expression and atresia during bovine follicle development. Reproduction 2001; 121:561-566.

20. Kadokawa H, Blache D, Yamada Y, Martin GB. Relationships between changes in plasma concentrations of leptin before and after parturition and the timing of first post-partum ovulation in high-producing Holstein dairy cows. Reprod Fertil Dev 2000; 12:405-411.

21. Soliman M, Ishioka K, Yoshida R, Komabayashi K, Hatai H, Matsui Y, Hirai T, Katagiri S, Takahashi Y, Kawakita Y, Abe H, Kitamura H, Kimura K, et al. Serum leptin levels during the periparturient period in cows. J Vet Med Sci 2002; 64:1053-1056.

22. Garcia MR, Amstalden M, Williams SW, Stanko RL, Morrison CD, Keisler DH, Nizielski SE, Williams GL. Serum leptin and its adipose gene expression during pubertal development, the estrous cycle, and different seasons in cattle. J Anim Sci 2002; 80:2158-2167.

23. Shin MR, Kim NH. Maternal gamma (gamma)-tubulin is involved in microtubule reorganization during bovine fertilization and parthenogenesis. Mol Reprod Dev 2003; 64:438-445.

24. Gallicano GI. Composition, regulation, and function of the cytoskeleton in mammalian eggs and embryos. Front Biosci 2001; 6:D1089-1108.

25. Brunet S, Maro B. Cytoskeleton and cell cycle control during meiotic 
maturation of the mouse oocyte: integrating time and space. Reproduction 2005; 130:801-811.

26. Lonergan P, Khatir H, Carolan C, Mermillod P. Bovine blastocyst production in vitro after inhibition of oocyte meiotic resumption for $24 \mathrm{~h}$. J Reprod Fertil 1997; 109:355-365.

27. Lee KS JB, Na YJ, Yoon MS, Choi OH, Kim WW. Cumulus cells apoptosis as an indicator to predict the quality of oocytes and the outcome of IVF-ET. J Assist Reprod Genet 2001; 18:490-498.

28. Mikkelsen AL, Host E, Lindenberg S. Incidence of apoptosis in granulosa cells from immature human follicles. Reproduction 2001; 122:481-486.

29. Kolle S, Stojkovic M, Boie G, Wolf E, Sinowatz F. Growth hormonerelated effects on apoptosis, mitosis, and expression of connexin 43 in bovine in vitro maturation cumulus-oocyte complexes. Biol Reprod 2003; 68:1584-1589.

30. Zeuner A, Muller K, Reguszynski K, Jewgenow K. Apoptosis within bovine follicular cells and its effect on oocyte development during in vitro maturation. Theriogenology 2003; 59:1421-1433.

31. Szoltys M, Tabarowski Z, Pawlik A. Apoptosis of postovulatory cumulus granulosa cells of the rat. Anat Embryol (Berl) 2000; 202:523-529.

32. Manabe N, Imai Y, Ohno H, Takahagi Y, Sugimoto M, Miyamoto H. Apoptosis occurs in granulosa cells but not cumulus cells in the atretic antral follicles in pig ovaries. Experientia 1996; 52:647-651.

33. Yang MY, Rajamahendran R. Morphological and biochemical identification of apoptosis in small, medium, and large bovine follicles and the effects of follicle-stimulating hormone and insulin-like growth factor-I on spontaneous apoptosis in cultured bovine granulosa cells. Biol Reprod 2000; 62:1209-1217.

34. Earnshaw WC, Martins LM, Kaufmann SH. Mammalian caspases: structure, activation, substrates, and functions during apoptosis. Annu Rev Biochem 1999; 68:383-424.
35. Deveraux QL, Stennicke HR, Salvesen GS, Reed JC. Endogenous inhibitors of caspases. J Clin Immunol 1999; 19:388-398.

36. Gardai SJ, Whitlock BB, Xiao YQ, Bratton DB, Henson PM. Oxidants inhibit ERK/MAPK and prevent its ability to delay neutrophil apoptosis downstream of mitochondrial changes and at the level of XIAP. J Biol Chem 2004; 279:44695-44703.

37. Jacobson MD, Weil M, Raff MC. Programmed cell death in animal development. Cell 1997; 88:347-354.

38. Yuan YQ, Van Soom A, Leroy JL, Dewulf J, Van Zeveren A, de Kruif A, Peelman LJ. Apoptosis in cumulus cells, but not in oocytes, may influence bovine embryonic developmental competence. Theriogenology 2005; 63: $2147-2163$

39. Motyl T. Regulation of apoptosis: involvement of Bcl-2-related proteins. Reprod Nutr Dev 1999; 39:49-59.

40. Yuan YQ, Peelman LJ, Williams JL, Van Zeveren A, de Kruif A, Law A, Van Soom A. Mapping and transcription profiling of CASP1, 3, 6, 7 and 8 in relation to caspase activity in the bovine cumulus-oocyte complex. Anim Genet 2004; 35:234-237.

41. Lonergan P, Rizos D, Gutierrez-Adan A, Fair T, Boland MP. Oocyte and embryo quality: effect of origin, culture conditions and gene expression patterns. Reprod Domest Anim 2003; 38:259-267.

42. Saeki K, Hoshi M, Leibfried-Rutledge ML, First NL. In vitro fertilization and development of bovine oocytes matured in serum-free medium. Biol Reprod 1991; 44:256-260.

43. Eckert J, Niemann H. In vitro maturation, fertilization and culture to blastocyst of bovine oocytes in protein-free media. Theriogenology 1995; 43:1211-1225.

44. Gardner DK. Mammalian embryo culture in the absence of serum or somatic cell support. Cell Biol Int 1994; 18:1163-1179. 